\title{
ABBREVIATIONS FOR REFERENCES
}

\section{Eighteenth-Century Periodicals and Newspapers}

Athenian Gazette . . Athenian Gazette; Or Casuistical Mercury, 20 vols. (London, 1690-1697).

G. ........... The Guardian (1713), 3rd ed., 2 vols. (London, 1747).

Review .........A Review of the State of the British Nation (1704-1711); Defoe's Review, reproduced from the original editions, with an introduction by Arthur Wellesley Secord, 22 vols. (New York, 1938).

S. $\ldots \ldots \ldots \ldots$ The Spectator $(1711-1714)$, ed. G. G. Smith, 4 vols. (London, 1907). Checked with the original folio sheets by S. Buckley and J. Tonson, and the first octavo edition (1712-1713) of the first seven volumes (Nos. 1-555), printed for S. Buckley and J. Tonson.

T. ........... The Tatler (1709-1711), ed. George A. Aitken, 4 vols. (London, 1898-1899).

WORKS OF ADDISON

Letters .......The Letters of Joseph Addison, ed. Walter Graham (Oxford, 1941).

Works ........ The Works of the Right Honourable Joseph Addison, ed. Richard Hurd. A new edition by Henry G. Bohn, 6 vols. (London, 1888-1892).

Works of Other Authors

CESC .......... Critical Essays of the Seventeenth Century, ed. Joel E. Spingarn, 3 vols. (Oxford, 1908-1909). Dennis ......... The Critical Works of John Dennis, ed. Edward Niles Hooker, 2 vols. (Baltimore, 19391943).

Descartes ....... The Philosophical Works of Descartes, trans. Elizabeth S. Haldane and G. R. T. Ross, 2 vols. 
Xii THE CULTURAL MILIEU OF ADDISON'S LITERARY CRITICISM (New York, 1955: reprint of corrected ed. of 1931).

EHU .........John Locke, Essay concerning Human Understanding, ed. Alexander Campbell Fraser, 2 vols. (Oxford, 1894).

Hobbes, Works ... The English Works of Thomas Hobbes, ed. William Molesworth, 11 vols. (London, 18391849) .

Lev. ......... Thomas Hobbes, Leviathan, introduction by A. D. Lindsay (New York, 1950) .

\section{Editions Cited}

Aristotle ......Works, The Oxford Translation, ed. J. A. Smith and W. D. Ross, 12 vols. (Oxford, 19101952).

Plato ......... The Dialogues of Plato, trans. Benjamin Jowett, 2 vols. (New York, 1937). 
Mr. Lock's Essay on Human Understanding would be thought a very odd book for a Man to make himself a Master of, who would get a Reputation by Critical Writings; though at the same Time it is very certain, that an Author who has not learned the Art of distinguishing between Words and Things, and of ranging his Thoughts, and setting them in proper Lights, whatever Notions he may have, will lose himself in Confusion and Obscurity . . .

The Truth of it is, there is nothing more absurd, than for a Man to set up for a Critick, without a good Insight into all the Parts of Learning; whereas many of those who have endeavoured to signalize themselves by Works of this $\mathrm{Na}$ ture among our English Writers, are not only defective in the above-mentioned Particulars, but plainly discover by the Phrases they make use of, and by their confused way of thinking, that they are not acquainted with the most common and ordinary Systems of the Arts and Sciences.

Addison, Spectator 29I 
THIS PAGE INTENTIONALLY LEFT BLANK 